\title{
Microhardness and Fracture Resistance of Radicular Dentin Treated with Different Concentrations of Calcium Hydroxide in Endodontic Regeneration Procedures
}

\author{
Sara N. Hashem ${ }^{1 *(D)}$, Maha Adel Elhousiny ${ }^{2}$ \\ ${ }^{1}$ Department of Pedodontics and Oral Health, Alazhar University for Girls, Cairo, Egypt; ${ }^{2}$ Department of Endodontics, Alazhar \\ University for Girls, Cairo, Egypt
}

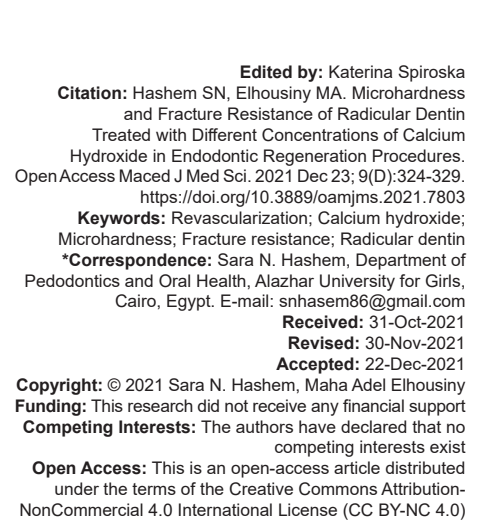

Abstract

AIM: To reveal the effect of different concentrations of prepared calcium hydroxide $\left(\mathrm{Ca}(\mathrm{OH})_{2}\right)$ pastes $(30 \%, 50 \%$, and $70 \%$ ) used in regenerative endodontic on microhardness and fracture resistance of radicular dentin.

MATERIALS AND METHODS: Different concentrations of $\mathrm{Ca}(\mathrm{OH})_{2}$ were prepared with measured $\mathrm{pH}$, then forty eight single rooted teeth were prepared and randomized into three groups according to $\mathrm{Ca}(\mathrm{OH})_{2}$ paste concentrations (12 samples each), and 12 samples were availed as control group. Group I: root canal contained $30 \% \mathrm{Ca}(\mathrm{OH})_{2}$ paste Group II: root canal contained $50 \% \mathrm{Ca}(\mathrm{OH})_{2}$ paste. Group III: root canal contained $70 \% \mathrm{Ca}(\mathrm{OH})_{2}$ paste. Samples were stored at $37^{\circ} \mathrm{C}$ with $100 \%$ humidity for four weeks for subsequent microhardness and fracture resistance tests.

RESULTS: There was a statistically significant reduction of microhardness and fracture resistance between test groups and control group ( $\mathrm{s} \leq .05$ ), Group III showed a significant reduction in both microhardness and fracture resistance compared to Group I. However, there was no significant difference in $\mathrm{pH}$ between different concentration of $\mathrm{Ca}(\mathrm{OH})_{2}$.

CONCLUSION: Increasing concentration of $\mathrm{Ca}(\mathrm{OH})_{2}$, paste can negatively affect microhardness and fracture resistance of radicular dentin in revascularization procedure.

\section{Introduction}

Endodontic treatment of immature necrotic teeth had been a problem for many years, as such teeth are usually have fragile short roots with thin dentin walls and wide open apical foramen [1].

Several approaches have been defined to obtain apical closure; one is apexification, which is known as formation of apical calcific barrier in a tooth with necrotic pulp. This calcific barrier is developed by promoting the formation of mineralized tissue at the root end, which occurs without actual root growth [2].

A major paradigm shift in treatment protocols from calcium hydroxide $\left(\mathrm{Ca}(\mathrm{OH})_{2}\right)$ apexification or placement of mineral trioxide aggregate apical barrier to a more dynamic management option of pulp regeneration targeting to regenerate the dentinpulp complex [3]. Recently, many clinical studies recommended the usage of regenerative endodontic procedures (REP) in the managing of such situations resulting in increased dentinal walls width and root growth induction [4]. Regarding clinical REP, The American Association of Endodontists suggests that the necrotic immature root canal be irrigated with 1.5\% sodium hypochlorite on the first visit, followed by the use of an intracanal medicament for 1-4 weeks to irradicate the canal microorganisms [5]. The most generally used intracanal medicines are $\mathrm{Ca}(\mathrm{OH})_{2}$ or triple antibiotic paste (TAP) which is a combination of ciprofloxacin, minocycline, and metronidazole. The biggest limitation of TAP is the darkening of young, immature teeth, which is thought to be induced by minocycline, and larger concentrations may disrupt stem cell vitality [6], [7].

$\mathrm{Ca}(\mathrm{OH})_{2}$ has long been used as an intracanal medicament because it has been able to neutralize the acidity of bacterial byproducts through its alkaline $\mathrm{pH}$ thus decreasing pain [8] Furthermore, $\mathrm{Ca}(\mathrm{OH})_{2}$ has been shown to be conducive to stem cells of the apical papilla survival and proliferation [9]. However, the use of $\mathrm{Ca}(\mathrm{OH})_{2}$ as intracanal medicament had a negative impact on the chemical structure of radicular dentin causing a negative effect on its mechanical properties [10], [11].

There are several $\mathrm{Ca}(\mathrm{OH})_{2}$ products are available in the market, and each with its composition, vehicles, and percentage concentration. In the previous literature, the impact of $\mathrm{Ca}(\mathrm{OH})_{2}$ concentration percentage on fracture resistance over time has not been well defined [12], [13], [14]. Thus, it isn't clear at what concentration exactly the mechanical properties of dentin can be affected. Thus, the concentrations of 
root canal medicament are crucial to find the balance between proper disinfection of the canal and preserving mechanical properties of radicular dentin in pulp regeneration process.

Therefore, the objective of this research was to investigate the impact of three different concentrations of $\mathrm{Ca}(\mathrm{OH})_{2}$ on root resistance to fracture and microhardness of radicular dentine. The null hypothesis was that there was no statistically significant change in microhardness and fracture resistance of radicular dentin when varied concentrations of $\mathrm{Ca}(\mathrm{OH})_{2}$ paste were used.

\section{Materials and Methods}

\section{Sample size calculation}

Sample calculation was carried out using the (power one way) command in STATA software (StataCorp LLC Stata/16.1, College Station, TX, USA). Reviewing the data from literature regarding mean load at fracture of different $\mathrm{Ca}(\mathrm{OH})_{2}$ formulations was $(40.44,37.99,40.98$ and 36.29) [14]. Power calculations using this data suggested that a total sample size of 48 samples ( $n=12$ in each) provides approximately $80 \%$ power at $50 \%$ level of significance.

\section{Selection of the samples}

Forty-eight anonymous extracted single rooted sound human permanent teeth with straight roots were used in this study. Initial radiographs were conducted to confirm that all teeth had mature apices, were free of previous endodontic treatment or root cracks and had no internal or external resorption, calcifications, or root caries. The use of extracted human teeth received ethical approval from the Research Ethics Committee (REC) of the College of Dental Medicine for Girls, Al Azhar University, in accordance with the Code of Ethics (REC-PD-21-07). The teeth were disinfected by immersion in $10 \%$ formalin for 2 weeks according to guidelines by center of the disease control [15].

\section{Preparation of $\mathrm{Ca}(\mathrm{OH})_{2}$ paste}

In this study, three different concentrations of $\mathrm{Ca}(\mathrm{OH})$, paste were prepared $(30 \%, 50 \%$, and $70 \%)$. To prepare $30 \%$ of $\mathrm{Ca}(\mathrm{OH})_{2}$ paste $(30 \mathrm{~g} / 100 \mathrm{ml})$ using the weight-in-volume (w/v) method, $30 \mathrm{~g}$ of pure $\mathrm{Ca}(\mathrm{OH})_{2}$ powder were mixed with $100 \mathrm{ml}$ of polyethylene glycol (PEG) 400 as a vehicle. Then, the mixture was put on magnetic stirrer for $10 \mathrm{~min}$, in the same technique the two other concentrations $50 \%$ and $70 \%$ were prepared using $50 \mathrm{~g} \mathrm{ca}(\mathrm{OH})_{2} / 100 \mathrm{ml}$ PEG 400 and

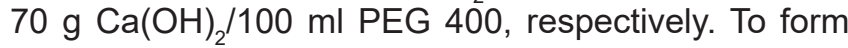

a homogeneous thick paste, $1 / 2 \mathrm{~g}$ of methylcellulose (MC) powder was mixed into $100 \mathrm{ml}$ of each solution by magnetic stirring [16], [17].

\section{Measurement of $\mathrm{pH}$ of different concentrations of $\mathrm{Ca}(\mathrm{OH}) 2$}

For measuring $\mathrm{pH}$ of different $\mathrm{Ca}(\mathrm{OH})_{2}$ concentrations in non-aqueous solution (PEG) 400, Metrohm solvotrode was used. Tetra Ethyl Ammonium Bromide $0.4 \mathrm{~mol} / \mathrm{L}$ in ethylene glycol was used as an electrode solution as its specially designed for measuring $\mathrm{pH}$ of highly alkaline solutions. Five separate preparations for each concentration were used for recording $\mathrm{pH}$, solvotrode electrode was placed in mixture, and $\mathrm{pH}$ was recorded at room temperature every 10 min for $2 \mathrm{~h}$ until a stable final measurement is reached [16].

\section{Preparation of the samples}

Endo $Z$ bur with water coolant at right angle to the long axis of the root were used in order to cut the root apex and standardize the root length to $10 \mathrm{~mm}$. Then, a conventional coronal cavity preparation was accomplished using size 4 carbide round bur. The root canal was prepared using the Pro Taper system rotary instruments at the following sequence: (Sx, S1, S2, $F 1, F 2, F 3, F 4, F 5)$, the first three shaping files were used with a brushing motion and the last five finishing files were used till the working length was reached. To simulate teeth with immature apices, peso reamers from \#1 till \#6 were introduced into root canals and a \#6 peso reamer was acceptable to extend $1 \mathrm{~mm}$ outside the apex to obtain apical diameter $\pm 1.7 \mathrm{~mm}$. The root canal was irrigated using $3 \mathrm{ml}$ of saline after each instrument using 27 gauge needle, and a final rinse with $20 \mathrm{ml}$ saline was performed then final dryness with paper points was done [17].

\section{Sample grouping}

The samples were randomly and equally allocated into three treatment groups according to the concentration of $\mathrm{Ca}(\mathrm{OH})_{2}$ each of 12 samples and 12 samples were serving as a fourth negative control group (Group IV). $\mathrm{Ca}(\mathrm{OH})_{2}$ with various concentrations (30\%, 50\%, and $70 \%$ ) were applied for Groups I, II, and III, respectively.

\section{Medicament application}

A plastic syringe with a 20-gauge needle was used to inject $\mathrm{Ca}(\mathrm{OH})_{2}$ paste into the canal according to each treatment group until it was extruded apically. The coronal and apical parts of specimens were coated with flowable composite, and then stored in an Eppendorf tube filled with saline at $37^{\circ} \mathrm{C}$ with $100 \%$ humidity for 
30 days. Saline was changed every week.

All specimens were embedded vertically in acrylic resin block then decoronated by a low speed diamond saw at a level $0.5 \mathrm{~mm}$ radicular to the facial CEJ under water cooling. Then, from each root, two root cylinders were sectioned horizontally. In fracture resistance testing, a cervical root cylinder with a $5 \mathrm{~mm}$ diameter was utilized, while microhardness testing was done with a middle $3-\mathrm{mm}$ root cylinder. $\mathrm{Ca}(\mathrm{OH})_{2}$ paste was removed by irrigation with saline [17].

\section{Microhardness test}

After transferring middle 3-mm root cylinders to the Vickers Hardness Testing Machine (Buehler, Lake Bluff, IL, USA) three indentations were done on the coronal polished surface of the specimens by a pyramid diamond indenter tip with $50 \mathrm{~g}$ load for $10 \mathrm{~s}$. dwell time. The indentations were measured using built in a microscope and Vickers hardness (HV) is calculated using: $\mathrm{HV}=1854.4 \mathrm{~L} / \mathrm{d}^{2}$ where the load $L$ is in $k g f$ and $d$ is the diameter of the prism in $\mu \mathrm{m}$. The mean of the three indentations' results was used to calculate the average hardness value for each specimen [18].

\section{Fracture resistance test}

A cervical $5 \mathrm{~mm}$ root cylinder embedded in acrylic resin block exposing $2 \mathrm{~mm}$ from coronal side used for fracture resistance test. The blocks with vertically aligned specimen were mounted in the

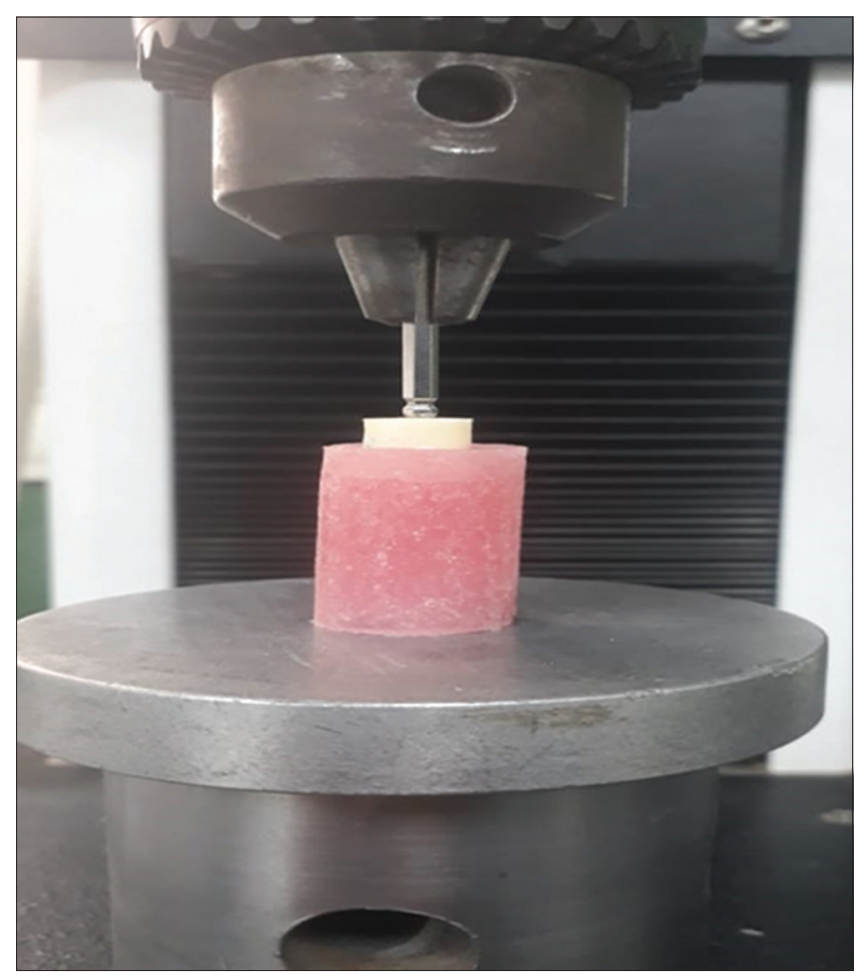

Figure 1: Fracture resistance test using instron machine fixed platform of universal testing machine (Instron, USA) (Figure 1). A Static vertical loading force $(5 \mathrm{kN})$ was inserted directly over the canal opening of each root, at a rate of $1 \mathrm{~mm} / \mathrm{min}$ till root cylinder fractured without any fracture to acrylic resin block. Fracture load value was recorded in Newtons by computer software [19].

\section{Statistical analysis}

All gathered data were tested for normality using Shapiro-Wilk test by STATA (StataCorp LLC Stata/16.1, College Station, TX, USA). The effect of different concentrations of $\mathrm{Ca}(\mathrm{OH})_{2}$ on microhardness and fracture resistance were evaluated using one-way ANOVA. For pairwise comparisons, Tukey's post hoc test was used. The level of significance was taken at $\mathrm{p}<0.05$.

\section{Results}

\section{The $\mathrm{pH}$ measurement of different} concentrations of $\mathrm{Ca}(\mathrm{OH})_{2}$

Results are listed in Table 1 as follow: The higher mean $\mathrm{pH}$ value was recorded for Group III $\left(70 \% \mathrm{Ca}(\mathrm{OH})_{2}\right)$, the lower value was recorded for Group I $\left(30 \% \mathrm{Ca}(\mathrm{OH})_{2}\right)$. The $\mathrm{pH}$ increased as the concentration of $\mathrm{Ca}(\mathrm{OH})_{2}$ increase; however, there was no significant difference between different concentrations of $\mathrm{Ca}(\mathrm{OH})_{2}$.

Table 1: Descriptive analysis of the $\mathrm{pH}$ among the studied groups

\begin{tabular}{lllll}
\hline Statistical & Groups & & & \\
\cline { 2 - 5 } parameters & Group I (30\%) & Group II (50\%) & Group III (70\%) & Significance test \\
\hline Mean & 13.908 & 14.382 & 14.633 & $\mathrm{P}=0.537$ \\
$\mathrm{SD}$ & 0.10910 & 0.1062 & 0.1758 & \\
\hline${ }^{*}$ Significant at $\mathrm{p}<0.05$. SD: Standard deviation. & & &
\end{tabular}

\section{Microhardness test results}

The mean microhardness, standard deviation (SD), and confidence interval (CI) for each group are presented in (Table 2). There was a significant difference between the microhardness of three test groups and control group. Furthermore, Group III $\left(70 \% \mathrm{Ca}(\mathrm{OH})_{2}\right)$ showed a significant reduction in the microhardness compared to Group I $\left(30 \% \mathrm{Ca}(\mathrm{OH})_{2}\right)$.

Table 2: Descriptive analysis of the microhardness among the studied groups

\begin{tabular}{lcccll}
\hline Group & Obs & Mean & SD & Lower bound & Upper bound \\
\cline { 5 - 6 } & & & & {$[95 \% \mathrm{Cl}]$} & \\
\hline Group I & 12 & 62.792 & 2.946 & 60.920 & 64.663 \\
Group II & 12 & 62.267 & 3.770 & 59.871 & 64.662 \\
Group III & 12 & 57.908 & 3.479 & 55.698 & 60.119 \\
Control & 12 & 69.175 & 2.245 & 67.749 & 70.601 \\
Total & 48 & 63.035 & 5.087 & 61.558 & 64.512 \\
\hline "Significant at $\mathrm{p}<0.05$. & & & &
\end{tabular}


However, no significant difference in microhardness between Group II and Group III.

\section{Fracture resistance results}

The mean comprehensive force essential to fracture the sample, SD, and $\mathrm{Cl}$ are presented in (Figure 2). There was a significant difference in the fracture resistance between the three test groups and control group after one month. Pairwise comparison revealed that Group III $\left(70 \% \mathrm{Ca}(\mathrm{OH})_{2}\right)$ showed a significant reduction in the fracture resistance compared to the other two concentrations $(30 \%$ and $\left.50 \% \mathrm{Ca}(\mathrm{OH})_{2}\right)$. In addition, no significant difference in fracture resistance between Group I and Group II.

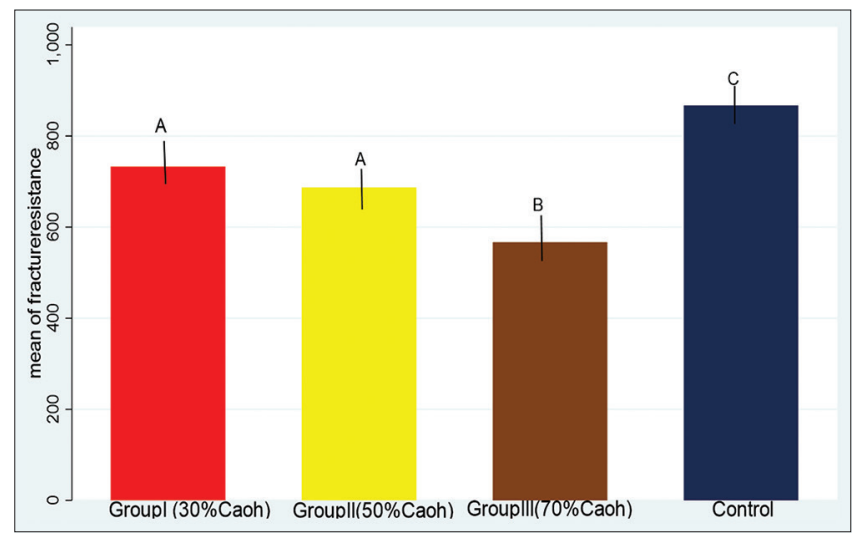

Figure 2: Bar graphs showing the effect of different concentrations of calcium hydroxide on fracture resistance radicular dentin comparing with the control group. Different letters indicate statistically significantly different $p<0.05$

\section{Discussion}

Successfulendodonticregenerative procedures depend on many factors; one of them is to preserve the mechanical, physical, and chemical properties of root dentin from any negative effects of chemical irrigation and medicaments used in REP [4]. Despite the fact that several studies have reported increases in the root dentin thickens and root lengthening, specialists continue to report horizontal fractures in teeth treated with regenerative techniques [13].

$\mathrm{Ca}(\mathrm{OH})_{2}$ was chosen to be intracanal medicament in this study as it possesses multiple properties such as, antimicrobial activity, tissue dissolving ability, inhibition of tooth resorption, and hard tissue formation, and has been associated with periradicular healing. In contrary to TAP, $\mathrm{Ca}(\mathrm{OH})_{2}$ is not cytotoxic to stem cells from the apical papilla or causing tooth discoloration [9]. However, dentin exposure to highly alkaline $\mathrm{Ca}(\mathrm{OH})_{2}$ medicament has been suggested to significantly decrease root resistance to fracture within 1 month [10].
As the concentration of $\mathrm{Ca}(\mathrm{OH})_{2}$ examined in various studies has been consistent, at this study different concentrations of $\mathrm{Ca}(\mathrm{OH})_{2}$ had been tested. A number of prior studies used a different form of commercially available $\mathrm{Ca}(\mathrm{OH})_{2}$, it reported conflict in the result which may be attributed to different formulations of $\mathrm{Ca}(\mathrm{OH})_{2}$ using numerous vehicles that could produce change in $\mathrm{pH}$ value in radicular dentin. pure $\mathrm{Ca}(\mathrm{OH})_{2}$ was not used as a positive control as a strong evidence confirmed its impact on weakening of the root [12], [13].

Sample standardization is a crucial factor for evaluating the effect of medicament on fracture resistance regarding dimension. In this study, root canal instrumentation was done to optimize the internal dimensions of roots before fracture resistance and microhardness tests. In addition, dentin thickness was standardized using a cervical 5- $\mathrm{mm}$ root cylinder for fracture resistance. A middle 3- $\mathrm{mm}$ root cylinder for microhardness test was chosen as, the increase in root wall thickness was found to be limited to mid- and/ orapical root structures in the majority of reported endodontic regeneration rather than the cervical part of the root, this also was used in a previous study [17]. Chemical irrigant used during regenerative endodontic therapy was reported to reduce microhardness and fracture resistance of root dentin, so saline was used as irrigant during root canal preparation and for removal of $\mathrm{Ca}(\mathrm{OH})_{2}$ paste [19].

$\mathrm{Ca}(\mathrm{OH})_{2}$ powder should be mixed with a liquid vehicle due to difficulty in delivery of dry $\mathrm{Ca}(\mathrm{OH})_{2}$ powder also liquid is essential for the release of hydroxyl ions. Most current $\mathrm{Ca}(\mathrm{OH})_{2}$ endodontic pastes available in the market use water as the vehicle. Water vehicle decreases the dissolution of $\mathrm{Ca}(\mathrm{OH})_{2}$ thus hinder highest $\mathrm{pH}$ that can be reached within the root canal system. By integrating non-aqueous vehicle such as the PEGs, faster hydroxyl ion release, greater dissolution and high alkaline $\mathrm{pH}$ can be reached, resulting in increased antimicrobial actions, and additional enhancements in biocompatibility and efficiency. As $\mathrm{Ca}(\mathrm{OH})_{2}$ chemical and physical properties, including ion release and viscosity, are influenced by the solvent utilized for this agent [14] It is fundamental to improve $\mathrm{Ca}(\mathrm{OH})_{2}$ physical and chemical properties without affecting mechanical properties of radicular dentin. It's assumed that adding a more viscous solvent will enhance clinical handle and reduce the frequency of hydroxyl ion release, resulting in fewer root canal re-dressings. For this reason, PEG 400 was used as vehicle in this study. MC was applied as thickening agent that added to different groups to obtain a clinical useable consistency and increase duration of therapeutic agent [16].

The alkaline characteristics of $\mathrm{Ca}(\mathrm{OH})_{2}$ may denature, dissolve, or neutralize acidic components in the organic matrix of dentin, such as acid proteins 
and proteoglycans, which function as bonding agents between hydroxyapatite crystal and collagenous network, thus weakening the radicular dentin. Therefore, $\mathrm{pH}$ of different concentrations of $\mathrm{Ca}(\mathrm{OH})_{2}$ was determined in this study [14]. However, there was no significant difference in $\mathrm{pH}$ between different concentrations of $\mathrm{Ca}(\mathrm{OH})_{2}$ but when comparing those values, it was above 12.4 which is the limit for water based $\mathrm{Ca}(\mathrm{OH})_{2}$. This can be adjusted for using PEG400 as a solvent. PEG can form complexes with calcium ions, as it contains large number of ethylene oxide groups in its structure. Such complex causes $\mathrm{Ca}(\mathrm{OH})_{2}$ to dissociate, releasing extra free hydroxyl ions [20].

This study found that increasing the concentration of $\mathrm{Ca}(\mathrm{OH})$, medicaments from $30 \%$ to $70 \%$ resulted in a significant reduction in microhardness and fracture resistance. This could be explained by the high alkalinity and low molecular weight of $\mathrm{Ca}(\mathrm{OH})_{2}$ which cause collagen matrix denaturation as anticipated in prior investigations [13], [14]. Another study revealed that 1 week of exposure to $\mathrm{Ca}(\mathrm{OH})_{2}$ induced considerable collagen breakdown in the superficial radicular dentine [7]; as known, collagen component is responsible for toughness of the hard tissues [21]. Moreover, this is in accordance with majority of literature studies listed in a systematic review which revealed a significant decrease in both microhardness and fracture resistance of root dentin by time [10]. However, another study examines fracture susceptibility after using 3 different formulation of $\mathrm{Ca}(\mathrm{OH})_{2}$ revealed that there was no significant difference after 6 month between negative control and the treated groups [13]. The null hypothesis that there was no statistically significant difference between different concentrations of $\mathrm{Ca}(\mathrm{OH})_{2}$ paste on microhardness and fracture resistance of radicular dentin was rejected as the higher concentrations of $\mathrm{Ca}(\mathrm{OH})_{2} 70 \%$ cause a significant reduction compared to control group on the other side there was no difference in fracture resistance and microhardness between $30 \%$ and $50 \%$ of $\mathrm{Ca}(\mathrm{OH})_{2}$.

\section{Conclusion}

Within the limitations of this study, the results suggested that:

1. There is a reduction of both microhardness and fracture resistance of radicular dentin by increasing the concentration of $\mathrm{Ca}(\mathrm{OH})_{2}$ paste

2. $\mathrm{PH}$ of $\mathrm{Ca}(\mathrm{OH})_{2}$ paste increase as its concentration increase.

\section{Recommendations}

Further studies to correlate different concentrations by the different time of applications.

\section{References}

1. Abd El Bary MK, El Shafei JM, Roshdy NN. Comparison of the effect of calcium hydroxide nanoparticles paste versus double antibiotic paste used in regenerative endodontic procedure on the chemical structure of radicular dentin (an in vitro study). Acta Sci Dent Sci. 2019;3(8):1-9. https://doi.org/10.31080/ asds.2019.03.0608

2. Dominguez Reyes A, Munoz LM, Martın TA. Study of calcium hydroxide apexification in 26 young permanent incisors. Dent Traumatol. 2005;21:141-5. https://doi. org/10.1111/j.1600-9657.2005.00289.x

3. Torabinejad M, Nosrat A, Verma P, Udochukwu O. Regenerative endodontic treatment, or mineral trioxide aggregate apical plug in teeth with necrotic pulps and open apices: A systematic review and meta-analysis. J Endod. 2017;43(11):1806-20. https://doi. org/10.1016/j.joen.2017.06.029

PMid:28822564

4. Antunes LS, Salles AG, Gomes CC, Andrade TB, Delmindo MP, Antunes LA. The effectiveness of pulp revascularization in root formation of necrotic immature permanent teeth: A systematic review. Acta Odontol Scand. 2016;74(3):161-9. https://doi.org/1 0.3109/00016357.2015.1069394

PMid:26179397

5. American Association of Endodontists: Considerations for Regenerative Procedures; 2018. Available from: http:/l www.aae.org/clinical-resources/regenerative-endodontics/ considerations-for-regenerative-procedures.aspx [Last accessed on 2018 Jan 04].

6. Mallishery S, Shah T. Regenerative endodontics-looking inward. J Adv Med Med Res. 2020;32(7):83-98. https://doi.org/10.9734/ jammr/2020/v32i730454

7. Yassen GH, Eckert GJ, Platt JA. Effect of intracanal medicaments used in endodontic regeneration procedures on microhardness and chemical structure of dentin. Restor Dent Endod. 2015;40(2):104-12. https://doi.org/10.5395/ rde.2015.40.2.104 PMid:25984471

8. de Rossi A. Effect of rotary or manual instrumentation, with or without a calcium hydroxide/1\% chlorhexidine intracanal dressing, on the healing of experimentally induced chronic periapical lesions. Oral Surg Oral Med Oral Pathol Oral Radiol Endodontol. 2005;5:628-36. https://doi.org/10.1016/j. tripleo.2004.07.018

PMid:15829889

9. Ruparel NB, Teixeira FB, Ferraz CC, Diogenes A. Direct effect of intracanal medicaments on survival of stem cells of the apical papilla. J Endod. 2012;38(10):1372-5. https://doi.org/10.1016/j. joen.2012.06.018 PMid:22980180

10. Yassen G, Platt J. The effect of non setting calcium hydroxide on root fracture and mechanical properties of radicular dentine: A systematic review. Int Endod J. 2013;46(2):112-8. https://doi. org/10.1111/j.1365-2591.2012.02121.x

PMid:22970899 
11. Eymirli S, Eymirli A. The effect of intracanal medication variations on microhardness of simulated immature root dentin. Aust Endod J. 2021 Dec;47(3):616-623. https://doi.org/10.1111/ aej.12532

\section{PMid:34062622}

12. Kahler W, Lin L. A review of regenerative endodontics: Current protocols and future directions. J Istanb Univ Fac Dent. 2017;51 Suppl 3:S41-51. https://doi.org/10.17096/jiufd.53911. PMid:29354308

13. Hawkins JJ, Torabinejad M, Li Y, Retamozo B. Effect of three calcium hydroxide formulations on fracture resistance of dentin over time. Dent Traumatol. 2015;31(5):380-4. https://doi. org/10.1111/edt.12175

PMid:25891936

14. Kahler SL, Shetty S, Andreasen FM, Kahler B. The effect of long-term dressing with calcium hydroxide on the fracture susceptibility of teeth. J Endod. 2018;44(3):464-9. https://doi. org/10.1016/j.joen.2017.09.018

PMid:29254817

15. Salem-Milani A, Zand V, Asghari-Jafarabadi M, ZakeriMilani P, Banifatemeh A. The effect of protocol for disinfection of extracted teeth recommended by center for disease control (CDC) on microhardness of enamel and dentin. J Clin Exp Dent. 2015;7(5):e552-6. https://doi.org/10.4317/jced.52280

PMid:26644828

16. Athanassiadis B, Walsh L. Aspects of solvent chemistry for calcium hydroxide medicaments. Materials. 2017;10(10):1219.

17. Prather BT, Ehrlich Y, Spolnik K, Platt JA, Yassen GH. Effects of two combinations of triple antibiotic paste used in endodontic regeneration on root microhardness and chemical structure of radicular dentine. J Oral Sci. 2014;56(4):245-51. https://doi. org/10.2334/josnusd.56.245

PMid:25500921

18. Topçuoğlu HS, Kesim B, Düzgün $S$, Tuncay Ö, Demirbuga $S$, Topçuoğlu $\mathrm{G}$. The effect of various backfilling techniques on the fracture resistance of simulated immature teeth performed apical plug with biodentine. Int J Paediatr Dent. 2015;25(4):248-54 . https://doi.org/10.1111/ipd.12137

PMid:25263283

19. Yassen GH, Vail MM, Chu TG, Platt JA. The effect of medicaments used in endodontic regeneration on root fracture and microhardness of radicular dentine. Int Endod J. 2013;46(7):688-95. https://doi.org/10.1111/iej.12046 PMid:23331240

20. Teoh YY, Athanassiadis B, Walsh LJ. The influence of aqueous and PEG 400 solvent vehicles on hydroxyl ion release from calcium hydroxide medicaments. Int Dent. 2016;11:42-50.

21. Shahdad SA, McCabe JF, Bull S, Rusby S, Wassell RW. Hardness measured with traditional vickers and martens hardness methods. Dent Mater. 2007;23(9):1079-85. https://doi. org/10.1016/j.dental.2006.10.001

PMid: 17141860 